\title{
Linguistic Manipulation Means in English Political Discourse
}

\section{Средства лингвистической манипуляции в английском политическом дискурсе}

Received: June 12, 2020
Accepted: September 14, 2020

Written by:

Liliya S. Polyakova ${ }^{8}$

https://orcid.org/0000-0002-9990-7694

Yulia V. Yuzhakova ${ }^{9}$

https://orcid.org/0000-0001-6790-044X

Tatyana Yu. Zalavina ${ }^{10}$

https://orcid.org/0000-0003-0210-7963

Natalya V. Dyorina ${ }^{11}$

https://orcid.org/0000-0002-0613-0864

\begin{abstract}
The scientific article presents a study of the ways of expressing manipulation in politics, which is performed in English political discourse by means of language. Carefully selected language units, used by politicians in public speaking, in combination with social factors, can be a powerful instrument for managing public opinion, i.e. manipulation. The authors analyze public speeches delivered by English politicians. Manipulation is an integral part of American political discourse, all speech strategies of which are aimed at one purpose: to influence a recipient, persuade him or her to make a decision that will be beneficial for a politician. The article considers the main strategies, tactics and types of manipulation used in the modern political sphere. An analysis of public speeches of English politicians proves the importance of speech manipulative techniques for successful achievement of political goals.
\end{abstract}

Keywords: language strategy, manipulation, manipulation tactics, political discourse, political language.

\begin{abstract}
Аннотация
В статье представлено исследование языковых средств манипулирования в англоязычном политическом дискурсе. Тщательно отобранные языковые единицы, используемые политиками в публичных выступлениях, в сочетании с социальными факторами, могут быть мощным инструментом управления общественным мнением, то есть манипулирования. Манипулирование является неотьемлемой частью политического дискурса, все речевые стратегии которого направлены на одну цель: оказать влияние на получателя, убедить его или ее принять решение, которое будет выгодно для политика. В работе рассматриваются основные стратегии, тактики и виды манипуляций, используемые в современной политической сфере. Цель исследования - анализ специфики использования приемов и средств языковой манипуляции в англоязычном политическом дискурсе.
\end{abstract}

Ключевые слова: языковая стратегия, манипулирование, тактика манипуляции, политический дискурс, политический язык.

\footnotetext{
${ }^{8} \mathrm{PhD}$ (Philology), Assoc. Prof. of Foreign Languages for Engineering, Education in the Humanities Institute, Nosov Magnitogorsk State Technical University, Magnitogorsk, Russia.

${ }^{9} \mathrm{PhD}$ (Philology), Assoc. Prof. of Foreign Languages in Engineering Department, Education in the Humanities Institute, Nosov Magnitogorsk State Technical University, Magnitogorsk, Russia.

${ }^{10} \mathrm{Ph}$. D. (Philology), Assoc. Prof. of Foreign Languages in Engineering Department, Education in the Humanities Institute, Nosov Magnitogorsk State Technical University, Magnitogorsk, Russia.

${ }^{11}$ Ph. D. (Philology), Assoc. Prof. of Foreign Languages in Engineering Department, Education in the Humanities Institute, Nosov Magnitogorsk State Technical University, Magnitogorsk, Russia.
} 


\section{Introduction}

Modern scientific research is characterized by increased interdisciplinary researched, and political linguistics is no exception. Since politics is interrelated with the media, the political discourse should be studied considering various political phenomena. Currently, in the information space, considerable attention of the audience is attracted not only to individual political leaders, but to the coverage of their actions or events.

Consequently, politics has become one of the most important elements of the functioning of modern society, designed to regulate the relationship of people within the society, to ensure the sustainability of social processes. The distinguishing features of political communication are publicity, one-direction (from a communicator to a recipient), unstable and heterogeneous character of the audience.

The language of politics affects the language, which can be explained by the following factors:

- the improving of methods of speech impact on the emotional-evaluation perception of political reality by the subject;

- the increased public interest in domestic and foreign policy issues posed by the changing world situation in the late 20th and early $21 \mathrm{st}$ centuries;

- the process of information society, as a result of which the language material, obtained by the subject through the media, prevails over other kinds of material. If earlier the language and speech were formed in relation to literature, now the language of printed and electronic media, which needs further investigation, is in the first place (Yuzhakova \& Polyakova, 2018).

As a rule, the study of the media is carried out on the basis of analysis of political discourse, as the studies in the field of political linguistics promote identifying new phenomena and techniques reflected in the language in connection with various changes and events in the world politics. Politicians often tend to veil their goals, which is one of the main features of political discourse and can be manifested in the language by nominalization, ellipses, metaphors, special intonation and other methods to influence the consciousness of the electorate and the opponents.

However, the interpretations of the term political discourse are still ambiguous: in some works the concept of political discourse is taken for granted without any explanation, while the others define the varieties or forms of political discourse as independent forms of discourse which are not correlated with it.

On this basis, it follows that the purpose of political discourse should be to convince the recipient, awakening his/her intentions to support the politician and encourage his/her action, for example, to vote (Yuzhakova \& Polyakova, et al., 2018). Accordingly, we can judge on the effectiveness of political discourse.

So the purpose of the given study is to identify and analyze the specifics of using the techniques and means of linguistic manipulation on the material of English political discourse.

The main research methods are the methods of discourse and text analysis, component analysis (analysis of the semantic components of lexical units), as well as general scientific methods of interpretation, comparison, abstraction and classification.

\section{The Present Study}

Modern media, devoted to political issues, are changing from informative to influential. They have an impact on "the man/woman's worldview, the way of his/her thinking, style, and type of culture (Gevorgian, 2011). The impact of the political text is increasing in the conditions of political instability, various crises and conflicts. During these periods, speech manipulation is actively used in political discourse to pressure the public consciousness, as its prime aims are to discredit the opponents, strengthen political position, and neutralize the negative public sentiment.

At present, regardless of the state, political scientists observe a low political culture, as the majority of the population finds it difficult to exercise their political choice on the basis of their own interests, which makes the problem of manipulation a relevant and significant issue. It should be noted that speech strategies in modern political discourse are aimed at the following motives: influencing the recipient, persuade him/her make the decision, desired for the political actor.

Manipulation in most studies is seen as a set of linguistic strategies characteristic to political discourse (Dyorina, et. al., 2017). This is due to 


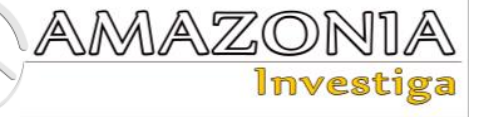

the fact that a language, or rather a word, in today's political arena is the main tool to exercise power, it is "the tool of social power" (Solovyova, 2014).

The deliberate, hidden nature of linguistic manipulation, as well as the diversity of verbal patterns, and their structural complexity, prove that manipulation has all the fundamental features of political communication. They are the focus on the influence, strategic, theatrics of language communication, and planned communication.

There are a lot of definitions of speech manipulation in the scientific literature. They come to the fact that it is the practice of human control over his/her consciousness and behavior, and the purpose of political manipulation is to receive, implement and maintain the power (Polyakova, 2010). It should be noted that manipulation in political discourse can be carried out by the means of speech, as well as by psychological influence. In psychology manipulation is described as a communicative influence, which leads to the mainstreaming of certain motivational states in the object of influence. They encourage the object to act in a beneficial manner for the subject. Meanwhile, it is assumed that this behaviour should not necessarily be unfavourable for the object of impact (Antropova, et. al., 2020). This interpretation is confirmed by Van Dijk, who states that speech manipulation is the selection and the use of such linguistic means, which make possible to influence the recipient of speech. The recipient does not realize this manipulation and perceives it as a part of objective information (Van Dijk, 2006).

Within the cognitive-discursive field of linguistics, two main approaches to the interpretation of the term manipulation can be identified. They are the pragmatic approach in the logic of D. Sperber and D. Wilson (Sperber, Wilson, 1995; Sperber, Girotto, 2002) and the approach within the critical discourse-analysis methodology described in the works of T. van Dijk (Dijk, 2001, 2006).

Discourse analysts view manipulation as a kind of argumentative discourse, which makes possible to reproduce and strengthen the power of a certain political group. Moreover, it makes the key role of a manipulator, who provides the impact via the manipulative discourse (Dijk 2006). At the same time, the representatives of the pragmatic concept believe that the manipulation is an artfully constructed context. It helps to deliver the information in such a way that, in the mind of the recipient of the text, providing several presuppositions, only those are manifested that are beneficial to the manipulator. Whereas, other presuppositions the context obscures or blocks (Maillat, 2013). Thus, the recipient of the text follows the path suggested by the manipulator. Nevertheless, the process of interpretation of the context is made by solely the interpreter.

According to Fairclough and Day, speech manipulation is a violation of argument, they call it pseudo-argumentation (Fairclough, 1989; Day, 1999). Others view manipulation as a means of achieving goals through persuasion (Kress, 1990; Van Dijk, T., 1996). However, the majority of scientists view manipulation as "the impact on a person with the aim to induce him doing something (to report some information, to take an action, to change his/her behavior). The respondent may do it either consciously or unconsciously against his/her own will, opinion, or intention".

The term comes from the Latin word manipulus which in the ancient Latin language had two meanings: 1) a hand folded as a handful, and 2) a military detachment consisting of 120 people (Solovyova, 2014). The Oxford English Dictionary gives the following definition of the word manipulation: «treating objects with special intentions, or a particular purpose». It emphasizes the message: "the act of influencing, manipulating people or things easily (with a negative connotation), it is a hidden treatment". The dictionary by Shvedova \& Ozhegov gives a clearer definition. It is a prank or a fraud (with a disapproving connotation) (Shvedova \& Ozhegov, 1996).

Depending on the nature of information transformations, the following types of manipulation are defined in political discourse:

1. Referential manipulation. It is associated with the distortion of the image of the denotate/referent in the process of the designation of reality. It can have several types.

a) Focus manipulation. It is a shift of pragmatic focus, when a view-point becomes different and, accordingly, the way of the denotat perception is being changed. It makes the recipient perceive it in favor of the manipulator.

b) Factual manipulation. It is a distortion of facts (lies, falsification of facts, 
exaggeration, innuendo, the creation of referential uncertainty).

2. Argumentative manipulation. It is associated with a violation of communication postulates, which can be manifested as follows.

a) A violation of the logic of text development or the wholeness of the text (e.g., avoiding of the answer, switching the topic of conversation); the omission of quantifiers accuracy and the introduction of the qualifiers of uncertainty (Tibunko, 2011);

b) The evasion of the duty to prove, such as the use of the immunization strategy, which means a formulation of a point of view in an irrefutable way that does not require any proof. Or the evasion of a complete presentation of information confirming the expressed point view, the omission of precision quantifiers and the introduction of uncertainty qualifiers, in particular.

- veiling of logical moves, such as the disguise of the assertion as presupposition or implication (Zakharova, 2009), objection under the guise of consent, and false arguments (Suvorova \&Polyakova, 2018). The distortion of information about the denotate can be presented in the form of two intersecting gradation scales. They are the axles of information space: a report about a fact - leaving something out (partial silence)

- complete silence (withholding the information);

- truth (full compliance with facts) - partial distortion - outright lie (complete distortion); so that the person himself/herself, because of reasoning or mental impulse, wanted to make that choice.

Thus, we view manipulation as a type of interaction between people, when one of them (a manipulator) tries to control the behavior of the other one (being manipulated), encouraging a person to behave himself/herself in an appropriate for a manipulator way, e.g. to vote for the candidate, to pay taxes, to buy goods, etc. As a rule, it is done in such a way that the manipulated does not realize himself/herself the object of influence, because the person believes that his/her own reasoning or mental impulse made him/her do it.

\section{Methodology}

The study is based on systematic approach to the discourse and text linguistics analysis.
Considering the cross-disciplinary approach as an integral part of political discourse, the anthropocentric factor was taken into account, i.e. linguistic and extra-linguistic data. In order to reach the above-mentioned goals of the study the following scientific methods have been used: continuous sampling method on the first stage of research.

On the second stage, we have distinguished the contexts of manipulative linguistic units used in political public speeches. Then, in order to find out the peculiarities of linguistic manipulative means contextual analysis, lingo-stylistical analysis and content analysis methods were used. At the final stage of the research all the obtained results have been analyzed with the help of component analysis (the semantic components of lexical units were analyzed), contrastivecomparative method, and have undergone linguistic interpretation.

The aim of any political leader is to win and retain the sympathy, affection, understanding, trust in himself/herself, and support of the citizens. However, it is seldom achieved with the help of "correct" rational persuasion, based on the logical evidence. This explains why political leaders quite often use certain kinds of manipulative tactics or "tricks" (Chilton, 2008; Thomas, 1995; O'Keefe , 2002; Kintsch, 1998), used in discussions, strategies and means of speech influence on feelings, emotions and the addressee's subconscious in order to create and maintain the desired image.

This task is accomplished through a set of language manipulation strategies in a political discourse:

- Identification formulas. They are the language means which encourage the recipient to identify himself/herself with the speaker, the politician's position, his/her party, evoke a sense of belonging, coalition, community, etc.

- Presenting a subjective opinion in the form of an objective fact or a truth that does not require any proof, in the form of a categorical judgment.

- The use of epistemic words. They are the words with the general meaning "to know," "to understand", e.g.: as we all know, there is no doubt that, etc. The choice of such words gives the political text the message of an unquestionable truth.

- Reference to authority. It is a strategy close to the abovementioned tactics, where a vision of the problem is offered by a certain 


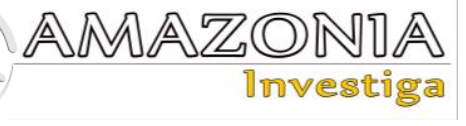

well-known person. This creates a situation when the audience is free of decisionmaking, as the conclusions have already been made by a more competent person. Though, at the same time, the politician himself/herself removes all the responsibility for the choice of the audience, because he/she "refers to someone's opinion".

- The expression of confidence of the speaker in the consent of the recipient.

It can be an appeal to a person's feelings, especially to the feelings of fear, anger, and hatred. As a rule, it is achieved through the emotionally-colored vocabulary, as the choice of certain words can make a person angry, intimidate him/her, and finally, determine his/her behavior. For example, the appeal to negative emotions, the tactic of anxiety is quite common for political discourse.

Another aspect used for language manipulation is a person's social well-being. The division into 'us' and 'them', the desire to be like everyone else, the awareness of one's own place in society, as well as the desire to make it better, all these significantly determine the behavior of the person. For example, by saying we, the author of the text as if unites his own point of view with the opinion of the audience.

Finally, a person's behavior is determined not only by emotions and the desire for selfaffirmation, but also by the ideas about the world, i.e. a picture or a model of the world. Language means can transform its components in such a way that the listener will not realize that he/she is the object of speech influence. The first tactic used for speech influence is the choice of words and expressions. In this case, the emotional impact is often combined with the marking of the relationship 'us' - 'them':

By choosing the right words, we can influence the picture of the reality as well. The use of euphemisms is more common, as they represent reality in a more favorable light.

Syntax also gives a lot of means of language manipulation, e.g.: passive instead of active voice, numerous sentence structures with verbal nouns (e.g. hostages captured, hostage-taking). When using a passive voice the real agent of the action may not be mentioned, as the situation comes to the fore, and there seems no one responsible for it.
Another effective means of manipulation is metaphors. They are closely connected with the model of the world. One of the most common speech tactics is the use of military metaphor.

Quite often manipulation is achieved with the help of presupposition. It is the information that is implicitly contained in the statement. Moreover, political communication is also characterized by almost all methods of 'unscrupulous' argumentation and verbal aggression, i.e. rather rude varieties of language manipulation.

There are various numerous language techniques of manipulation, so it is not possible to create a single classification of the combination of verbal and non-verbal means of manipulation in interpersonal communication, in the manipulation of the electorate during political campaigning, as well as in the formation of public opinion in the media. However, political discourse provides an opportunity to identify common features inherent in linguistic manipulation.

Quite interesting is the method of distinguishing the tactics of speech impact, suggested by V. E. Chernyavskaya (Chernyavskaya, 2006), which is put forward by P. B. Parshin (Parshin 1986). The authors view the structure of the manipulative communication as the choice of linguistic means at various levels of a language. They are syntactical, lexico-semantic, and rhetorical-stylistic means of language manipulation (Polyakova \& Yuzhakova, 2017).

Thus, it is obvious that at the moment there is no generally accepted classification of speech manipulation techniques, and there is no single terminology in this field. Researchers outline two main trends when analyzing this topic. Some scientists simply give a list of speech manipulation techniques; others offer a variety of classifications, which are highlighted on various bases and differ from each other.

\section{Results and Analysis}

The purpose of this study is to reveal the manipulative nature of political discourse on the example of public speeches by U.S. politicians. Let's follow the levels and techniques of manipulative influence on the example of the article"Trump - Russia dossier: why its findings grow more significant by the day" published on the Guardian's website (https://www.theguardian.com) on October 7, 2017. 
The title of the article, as well as the first phrase of any utterance, firstly, performs the function of attracting the recipient's attention. That is why the headlines are generally quite bright and expressive, and emotionally colored. Secondly, the title reflects the content of the entire text. From the title the reader should get the answer to the question what this article is about and, accordingly, make a choice whether to read this text or not. The headline under consideration contains several linguistic levels (lexical, grammatical, stylistic, pragmatic), and the tactics of manipulation.

The first part of the headline, the phrase Trump Russia dossier, is a name-calling structure, expliciting the existence of a dossier, who, apparently, has got the facts concerning the president of the United States and Russia. However, thanks to the media coverage and the conjunctionless clause Trump - Russia, this word combination implicits the existence of some real relationship between the president of the U.S. and Russia. This kind of relationship should be evaluated negatively by the English-speaking reader. It can be partially explained due to the information coverage which has promoted forming a negative attitude towards Russia in the mind of an average English-speaking reader. In other words, the concept "Russia" is more negative in the English variant. The second part of the title, judging by the syntax structure (asyndeton, framed by a colon), proves, explains and develops the idea expressed in the first part of the sentence (Trump's relationship with Russia). The manipulative potential of the second part is also realized by contrasting explicit and implicit information. The explicit information, a special indirect question why its findings grow more significant by the day show the author's neutral intentions to the reader, as well as his desire to tell the truth. However, this sentence, by its modality and a question form, contains a proposition "the significance of the data is growing every day", which is introduced into the mind of the recipient, as a statement of fact, and implicits the existence of real evidence of relations of Trump with Russia.

Further, the author clarifies and develops the information contained in the headline of the article, namely the idea of Trump's ties to Russia is developed: As US officials investigate potential collusion between Trump and Moscow, the series of reports by the former UK intelligence official Christopher Steele are casting an ever darker shadow over the president. To develop a negative image of President Trump, created in the headline, the author uses the technique of graduation. It is expressed by a complex sentence with an adverbial clause of time. The first part of the sentence, As US officials investigate potential collusion between Trump and Moscow, an adverbial clause of time, contains a link to the idea reflected in the title potential collusion.

This idea is expressed through the combination of an adjective potential which includes a seme of uncertainty about the veracity of the facts, and a noun collusion which has negative connotations. Thus, in the first introductory part of the article, the author repeats the information from the title and implicits the possible fault of the president in the above action collusion and his uncertainty about the veracity of the information. The second introductory part of the article is the main clause in the complex sentence, which shows an increase in negative assessment of the activities of the president. This is explained by the use of bright stylistic devices, like metaphors (e.g. cast a shadow over the president). It implies some unseemly acts that form a negative attitude towards the president. A comparative degree of adjective (an ever darker shadow) implies more unfavorable acts than those mentioned earlier. Thus, in the introductory part of the article such stylistic means as gradation and metaphor were used, which contribute to the influence on the mind of the recipient and the development of the negative image of President Trump. In other words, they are used for manipulative purposes.

The main part starts with the following sentence: It was reported this week that the document's author, former British intelligence official, Christopher Steele, has been interviewed by investigators working for the special counsel on Russian interference in the 2016 election. First of all, it should be noted that the phrase Russian interference in the 2016 election is presented to the reader with a modality of the statement of a fact, i.e. as an immutable truth.

The addressee perceives the information, framed in such a way as a given, as the truth or an axiom. In other words, the reader is deprived of the opportunity to think whether the presented information corresponds to reality. Thus, the modality of the statement of the fact contributes to the introduction of the desired to the referee attitude into the mind of the recipient, which, accordingly, contributes to the realization of the author's manipulative intentions. 


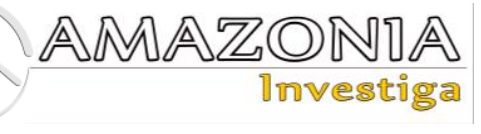

In the same passage of the article, we can find a violation of the maxim of the amount of information by G. Grice, which is quite often used for the purpose of manipulation. It states that Christopher Steele, has been interviewed by investigators working for the special counsel on Russian interference in the 2016 election. The addressee, receiving additional information about the investigators who, as it turns out, also work for a special adviser on Russian interference in the 2016 election, mentally links the two "cases" and forms the idea that the Russians are really involved in both the events described above.

Another feature of this article is the fact that Christopher Steele's "unanimated" reports are often used as the agent: ...the series of reports ... are casting an ever darker shadow...; ...the set of intelligence reports... is still hanging over Washington, casting a shadow over the Trump administration...; ... they cite a range of unnamed sources... . Such personification of "unanimated" reports performs several related functions: on the one hand, the author of the article acts as an objective observer, only relating the contents of the above-mentioned documents. On the other hand, the evaluative information, provided by the author as the contents of the document, i.e. with the modality of the statement of fact, is uncritically perceived by the reader and is relatively easily embedded in his/her consciousness. The seeming objectivity of the author, and his non-involvement facilitates the process.

The so-called "numerous anonymous sources", designed to introduce the necessary assessment of the events described by the author into the reader's mind, perform a similar function in the text of the article. They give a reader the impression that, in fact, the author of the article only transmits the known information obtained from real sources. The number of sources and their apparent objectivity help convince the reader in the veracity of the received information. However, the manipulative potential of the article will drop dramatically if the reader starts thinking about the type of sources of the obtained information, and the reasons why they are not mentioned in the article.

... they cite a range of unnamed sources, in Russia and the US, who describe the Kremlin's cultivation over many years of the man who now occupies the Oval Office - and the systematic collusion of Trump's associates with Moscow to help get him there.
The information, provided in the passage under consideration by "anonymous sources", is a neutral description of the situation. It is a simple listing of facts, devoid of explicit assessment, which should indicate objectivity and the author's impartiality and "sources". To achieve this effect, the author uses nominative clauses, formally devoid of appraisal: Kremlin's cultivation; the systematic collusion of Trump's associates with Moscow. However, these clauses contain concepts Kremlin and Moscow, that highlight the opposition "us" - "them" and, therefore, cause a negative assessment of the described actions in the mind of the English-speaking reader. It is true particularly given the current information background in the world media.

On the one hand, the speakers' quotation and indirect speech show the author's impartiality and objectivity. On the other hand, they are designed to introduce the ideas and assessments, desired for the author of the article, into the mind of the recipient, i.e. they can be used in manipulative purposes of the author (Yuzhakova, 2007). At the same time, the author can use different tactics. For example, he/she may use indirect characteristics of the speakers describing their worldviews, their affiliation to the parties, nationalities, places of employment and positions. These indirect characteristics of the speakers, presented in the author's remarks, serve as a means of highlighting the opposition "us" "them" and guide the reader in the axiological space of the text. The point of view and the assessment of the situation, expressed by "us" (a representative of our country, our social group, our party) is more likely to receive a response in the mind of the recipient and will be evaluated positively. This kind of view-point is easier to introduce into the reader's mind.

For example, the sentence «Even a senior Republican, Richard Burr, the chairman of the Senate intelligence committee, admitted this week it was an open question» contains the following author's remark: Even the senior republican, Richard Burr.... This remark may imply the following: even Trump's party member, not the last person in the party, who is an intelligence expert, believes that accusations against Trump may have some basis. In other words, since the president's supporters and party fellows admit the possibility of the accusations verity, the reader has every reason to consider them to be true. Further, to enhance the impact on the addressee and to develop his or her confidence in Trump's fault, the author uses Burr's indirect speech: In his remarks this week, Burr said his committee had come to a consensus 
in supporting the conclusions of a US intelligence community assessment in January this year that Russian had conducted a multi-pronged campaign to interfere in the 2016 election, in Trump's favour. This remark contains the accusation of Russia in interfering in the 2016 election. It should be stressed that the author uses the state of the fact modality, thus presenting the unsupported information as true: Russian had conducted a multi-pronged campaign to interfere in the 2016 election, in Trump's favour (Русские провели многоэтапную компанию по вмешательству в выборы 2016 года в пользу Трампа). To make the reader believe the above viewpoint, the author cites the opinion of intelligence related sources, which is supposed to lend credence to the author's words. Since several sources of this kind and the same opinion are mentioned, the reader can absolutely be sure that they are credible: committee had come to a consensus; a US intelligence community assessment. Comparing the two Burr's indirect speeches considered above: "... admitted this week it was an open question" and "Russian had conducted a multi-pronged campaign to interfere in the 2016 election, in Trump's favor... “, we can say that the author applies a peculiar gradation technique, vividly demonstrating the change in Burr's opinion about the question of Russia's intervention in the American elections. Such a change in Burr's attitude, based on the study of information from several credible related to intelligence sources, is another means to prove the validity of the charges against Trump.

To produce a desired impact on the addressee, the author uses another technique based on the application of quotations and indirect speech. He quotes opinion of many, sometimes even opposing, parties, setting forth the same vision of events, which is supposed to prove its objectivity and facilitate the introduction of the corresponding viewpoint into the consciousness of the addressee.

For example, the author supports a rather controversial phrase: "Russian had conducted a multi-pronged campaign to interfere in the 2016 election, in Trump's favor" with the following sentence: "It is a finding that echoes the reports that Steele was producing seven months earlier. Trump has called the assessment a "hoax", but there is no sign the three agencies that came to that conclusion, the CIA, FBI and NSA, have had any second thoughts in the intervening months". Here, Trump's statement is contrasted with conclusions made by such significant organizations as the CIA, the FBI, and the NSA, acting in a cohesive way. Which opinion will be more relevant for the reader? So, the author uses the opposition and references to the reputable sources opinion in order to instill the necessary conclusions to the addressee.

Having formed a certain reader's attitude to the described events (it has become clear who tells the truth and who doesn't, who is good and who is bad) the author proceeds to the further development of this topic; namely, to revealing Trump's supposedly false statements, in order to once again emphasize that one cannot believe his words. To this end, the author again uses indirect speech and quotations: After the meeting was first reported on 8 July this year, the president's son claimed (in a statement dictated, it turned out, by his father) that it had been about adoptions of Russian children by Americans. The next day that was exposed as a lie, with the publication of emails that made it clear that Veselnitskaya was offering damaging material on Hillary Clinton, that an intermediary setting up the meeting said was "part of Russia and its government's support for Mr Trump".

The above passage contains an opposition of the Trump's son's words about a meeting with a lawyer Natalia Veselnitskaya (it had been about adoptions of Russian children by Americans) and a certain intermediary's words, who has organized the meeting (part of Russia and its government's support for Mr Trump). In fact, the second remark represents the words of an unknown anonymous source, which few people would listen to in a different situation. However, the previous part of the article has already "prepared" the reader to the desired understanding, oriented him in the axiological space of the text, and divided the characters into "positive" and "negative" ones. Therefore, the words of an anonymous source are not perceived as an unsubstantiated accusation, but as an evidence of Trump's lies.

It is due to the application of the othering strategy: the author uses hint-remarks in the form of concepts of the Kremlin, Russian power, Moscow, etc., which mark the opposing side ("the aliens") and help the reader choose and stick to the "correct" viewpoint.

Steele quoted a source as saying that "the Kremlin had been feeding Trump and his team valuable intelligence on his opponents, including Democratic presidential candidate Hillary Clinton", for several years. 


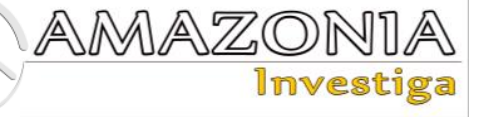

Source E, an ethnic Russian close associate of Republican US presidential candidate Donald Trump, admitted that there was a well-developed conspiracy of cooperation between them and the Russian leadership.

Steele's sources describe him as an "intermediary" between Manafort and Moscow. The article finishes with the words: «But the dossier has not faded from view. Instead, it appears to be growing in significance as the investigations have gathered pace».

This text is devoted to the so-called dossier on Russia's assistance to Trump in the presidential election in 2016. The dossier was compiled by the former British intelligence officer Christopher Steele. This text is based on the consideration of information provided by different sources that is why the text is based on quotes, quotations and indirect speech. Formally, the author is removed from commenting on the replicas, thus making the impression of noninterference in the recipient's course of thoughts. It helps to create confidence among the recipients that they themselves have come to final conclusions, or, in other words, it is the tool of manipulating the audience.

\section{Conclusion}

From the point of view of modern linguistics, political discourse is the material of studying the effectiveness of speech influence on the listener. Pre-election debates, parliamentary speeches, electoral technologies and campaigns are fundamental concepts of political discourse and speech manipulation. One of the mechanisms of speech manipulation in political discourse is the mechanism of influence on stable forms of consciousness. This impact occurs when the addressee can appeal to the listener's stereotypes. This is the basis of the technique of speech manipulation in the field of political discourse. Therefore, speech manipulation creates certain stereotypes and preferences, beneficial to the addressee.

Thus, the purpose of speech manipulation in political discourse is to convince the recipient in the idea that the decision is made solely by $\mathrm{him} / \mathrm{her}$, and that it is the listener's own decision. Therefore, speech influence in political discourse is a necessary tool which can help to manipulate the behavior, thinking and consciousness of the mass audience, as manipulation is aimed at changing the behavior of the recipient.
The foregoing leads to the conclusion that the communicative strategy of manipulation is common for modern political discourse, as it successfully solves the tasks of the implied imposing of the speaker's opinion to the listener. A characteristic feature of English political discourse is language manipulation, which is a holistic speech action aimed at the mass addressee in order to gain and retain power.

Carefully selected language units, used by politicians in public speaking, in combination with social factors, can be a powerful instrument for managing public opinion, i.e. manipulation. The main task of manipulators is to stereotype social and political reality through a language. It can be concluded that manipulation has a special place in English political discourse. Therefore, politicians' public speeches are, as a rule, created with the ultimate aim: to influence people's consciousness through thoughtful and proven techniques, namely linguistic means.

\section{References}

Antropova, L., Zalavina, T., Polyakova, L. \& Yuzhakova, Y. (2020). Extralinguistic Conditions of Language Variability in National Languages. Amazonia Investiga, 9(25), 266-273. Retrieved

from https://amazoniainvestiga.info/index.php/amazo nia/article/view/887

Chernyavskaya, V.E. (2006). Discourse of power and power of discourse. Speech Impact Problems [Discourse of power and power of discourse. Problems of speech impact], Moscow, Nauka Publ., 136 p.

Chilton, P. (2008). Political Terminology. In Karlfried Knapp and Gerd Antos (eds.). Handbook of Communication in the Public Sphere. Handbooks of applied linguistics Vol.4. Berlin: Walter de Gruyter GmbH\& Co.

Day, N. (1999). Advertising: Information or Manipulation?, Springfield, NJ: Enslow.

Dyorina, N., Savinova, T., Zalavina, T., Zerkina, N., Kisel, O., et al. (2017). Polydiscursive Space: the Word, the Text, the Communication. Magnitogorsk: NMSTU.

Fairclough, N. (1989). Language and Power. London: Longman.

Gevorgian, M.V. (2011). Actualization of the tactics of language manipulation in mass media political discourse. Political linguistics. 4 (38). 76-78.

Kintsch, W. (1998) Comprehension: A Paradigm for University Press. Cognition. Cambridge: Cambridge,

Kress, G. (1990). Critical discourse analysis. Annual Review of Applied Linguistics. Vol. 11. 
Cambridge: Cambridge University Press. pp.3-9, 11-13

Maillat, D. (2013). Constraining context selection: on the pragmatic inevitability of manipulation. Journal of Pragmatics (special issue Biases and constraints in communication: argumentation, persuation and manipulation). 59, Part B, 190-199

O'Keefe, D.J. (2002). Persuasion: Theory \& Research. Thousand Oaks CA: Sage

Parshin, P.B. (1986). Linguistic methods in conceptual reconstruction. Systems research. The annual review 1986. Moscow. pp. 398-425.

Polyakova L.S. \& Yuzhakova Yu. V. (2017) The peculiarities of mediatext translation (on the example of "Daily Mail" article "Tsar Harry!") Humanitarian and pedagogical researches, V.1, № 1, pp. 136-143

Polyakova, L.S. (2010). Speech Infuence: Theoretical aspects. Actual problems of philology and pedagogical linguistics, 12, 118-121.

Solovyova, E.V. (2014). Communicative strategy of manipulation in modern German political discourse (on the example of a speech act of indignation). The Herald of Nizhny Novgorod University. No 2. 403-406.

Sperber, D, and Wilson, D. (1995). Relevance: Communication and Cognition. Oxford: Blackwell.2
Suvorova, E.V. \& Polyakova, L.S. (2018). Types of inferences in discourse. Arab World English Journal, 9 (1), 294-306.

Van Dijk, T. (1996) 'Discourse, Opinions and Ideologies', in C. Schäffner and H. KellyHolmes (eds) Discourse and Ideologies, pp. 7-37. Clevedon: Multilingual Matters.

Van Dijk, T. (2001). Multidisciplinary CDA: A Plea for Diversity. In Methods of Critical Discourse Analysis, ed. by Ruth Wodak and Michael Meyer, 95-120. London: Sage.

Van Dijk, T. (2006). Discourse and Manipulation. Discourse and Society, 17 (2), 359-383.

Yuzhakova, Yu. V. (2007). Implicit expression of negative evaluation as a manifestation of tolerance. Proceedings from the 10-th International Conference: Issues of Modern Philology and Methods of Language Teaching at University and School. Penza: RIO PGSHA, 109-111.

Yuzhakova, Yu. \& Polyakova, L. (2018). Ethnic stereotypes in English political discourse. Philological Science. Questions of theory and practice, 199-202.

Yuzhakova, Yu., Polyakova, L., Dyorina N. \& Zalavina, T. (2018). Peculiarities of ethnic stereotypes usage in English political discourse. Arab World English Journal, 9 (4), 464 - 472.

Zakharova, V.A. (2009). The means of actualizing the target of "fear" of manipulation in political discourse. The system of values of modern society, 5 (1), 102-107. 